\title{
nombalina
}

(8)

\section{Os estudos de Camões}

Autor(es): Ramalho, Américo da Costa Publicado por: $\begin{aligned} & \text { Imprensa da Universidade de Coimbra; Fundação Eng. António de } \\ & \text { Almeida }\end{aligned}$

URL

persistente:

URI:http://hdl.handle.net/10316.2/32429

DOI:

DOI:http://dx.doi.org/10.14195/978-989-26-0427-5_5

Accessed : $\quad$ 26-Apr-2023 13:49:18

A navegação consulta e descarregamento dos títulos inseridos nas Bibliotecas Digitais UC Digitalis, UC Pombalina e UC Impactum, pressupõem a aceitação plena e sem reservas dos Termos e Condições de Uso destas Bibliotecas Digitais, disponíveis em https://digitalis.uc.pt/pt-pt/termos.

Conforme exposto nos referidos Termos e Condições de Uso, o descarregamento de títulos de acesso restrito requer uma licença válida de autorização devendo o utilizador aceder ao(s) documento(s) a partir de um endereço de IP da instituição detentora da supramencionada licença.

Ao utilizador é apenas permitido o descarregamento para uso pessoal, pelo que o emprego do(s) título(s) descarregado(s) para outro fim, designadamente comercial, carece de autorização do respetivo autor ou editor da obra.

Na medida em que todas as obras da UC Digitalis se encontram protegidas pelo Código do Direito de Autor e Direitos Conexos e demais legislação aplicável, toda a cópia, parcial ou total, deste documento, nos casos em que é legalmente admitida, deverá conter ou fazer-se acompanhar por este aviso.

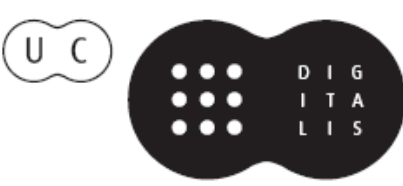




\title{
Instituto de Estudos Clássicos
}

\section{Um Passado com Futuro}

\author{
60 anos de actividade
}

cientifica, pedagóogica e cultural
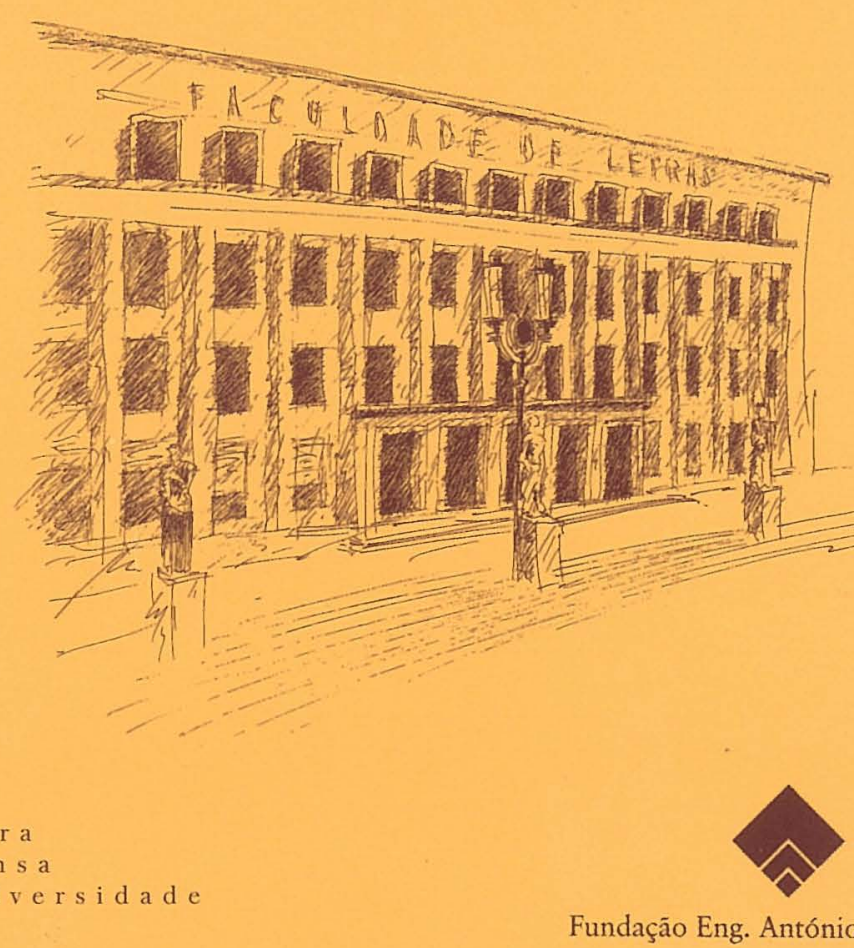

I m prens a

d a Un iversida de

2005

Fundação Eng. António de Almeida 


\author{
DELFIM F. LEÃ0 \\ Coordenação
}

\title{
Instituto de Estudos Clássicos
}

\section{Um Passado com Futuro}

60 anos de actividade

cientifica, pedagóggica e cultural 


\section{Coordenação editorial}

Imprensa da Iniversidade de Coimbira

\section{Concepção gráfica}

António Barros

\section{Execução gráfica}

Imprensa de Coimbra, Lda

Couraça dos Apóstolos, 126

3000-372 Coinubra

ISBN

$972-8704-44-5$

\section{Depósito Legal}

$224.950 /(0.5$

(1) 2005, Imprensa da Universidade de Coimbra 
(Página deixada propositadamente em branco) 


\title{
Os Estudos DE CAMÕES*
}

\author{
OraÇÃo de SAPIÊNCIA
}

PELO

\section{PROF. DOUTOR AMÉRICO DA COSTA RAMALHO}

(1980)

Dos vários assuntos que podia abordar nesta lição inaugural, relacionados com a cultura greco-latina em que me formei e conquistei graus académicos e com o mundo cultural do século XVI em que têm decorrido as minhas pesquisas de investigador, pareceu-me que era neste último domínio que devia situar-se a lição de hoje. Celebramos em 1980 os quatrocentos anos da morte do maior poeta de língua portuguesa, falecido em Lisboa, em 10 de Junho de 1580.

Aos que andam menos informados das razões por que a efeméride se encontra fixada com tanta precisão, lembrarei que numa ementa ou registo abreviado, existente no Arquivo Nacional da Torre do Tombo, e com data de 13 de Novembro de 1582, se manda pagar, à mãe de Luís de Camões, uma quantia devida ao filho, "do primeiro de Janeiro do anno de LXXX ate dez de Junho delle em que faleceo".

Oxalá estivéssemos informados com igual segurança de outros factos da existência do poeta!

Mas se as vicissitudes do homem, numa «vida em pedaços pelo mundo repartida», como ele mesmo escreveu, nos escapam, e nos não permitem a

\footnotetext{
* Texto publicado em Miscelânea de Estudos.
} 
segurança necessária para fazer uma biografia crítica, há aspectos do seu mundo espiritual que podemos colher dos versos e das cartas, com relativa segurança.

Uma questão prévia a levantar, entretanto, é a de saber se um poeta deve ser julgado pela sua cultura.

Que há no poeta - e refiro-me em especial àquele capaz de marcar uma época -, que há no poeta de diferente dos outros artistas da palavra? É pela cultura que ele se distingue dos restantes escritores?

Não, necessariamente. Acima da cultura está aquele quid inexplicável, inexprimível, - usarei um latinismo -, inefável (incflabile) da poesia, que os antigos qualificavam de divino e que prende e arrasta sentidos e pensamento, sem que se saiba muito bem porquê.

Os latinos diziam poeta nascitur, orator fit: «o poeta nasce, o orador faz-se». Este «faz-se» significa por extensão, "torua-se, devém». Entretanto, será talvez conforme com a realidade dizer que o poeta nasce e se faz.

Mas a poesia, seja qual for, reflecte sempre uma cultura, ainda quando não possa chamar-se-lhe culta e ela se proclame até avessa à cultura, o que não é o caso presente.

Em Camões, esta verdade óbvia verifica-se em toda a sua obra, na lírica tanto como na épica ou na dramática. E a cultura do seu tempo e do seu meio que espontaneamente se nos revela, mesmo quando o poeta parece não ter esse propósito. Mas há também a voluntária expressão de um saber complexo, na sequência de uma tradição que vinha de longe e nele se mantém viva. Assim procedendo, Camões não faz mais do que continuar os alexandrinistas romanos, os poetae docti, poetas doutos do final da República e do começo do Império e subsequentes, de Catulo e Lucrécio a Virgílio, Horácio, Ovídio e os épicos tardios da literatura latina.

Para esses poetas, o verso era um meio de transmissão, em ritmo e harmonia sonora e interior, do saber do seu tempo, numa época da história em 96 que ainda era possível ao homem cultivado abranger o conjunto da tradição literária, da reflexão desinteressada e dos conhecimentos úteis, então disponíveis. Era isso que aos olhos dos contemporâneos fazia do poeta humanissimus, um homem civilizado, noção que virá a tomar-se, no tempo de Camões, uma das componentes do conceito de humanista.

Falando do Parnaso, a colectânea dos versos que roubaram ao poeta, escreveu Diogo do Couto, no capítulo 28, da Década VIII: «Em Moçambique achámos aquele Príncipe dos Poetas do seu tempo, meu matalote e amigo 
Luís de Camões (...) e aquele Inverno que esteve em Moçambique acabou e aperfeiçoou as suas Lusiadas para as imprimir, e foi escrevendo muito $\mathrm{cm}$ um livro que ia fazendo, que se intitulava Panasso de Luiz de Camóes, livro de muita erudição, doutrina e filosofia, o qual the furtaram e nunca pude saber no Reino dele, por muito que o inquiri, e foi furto notável; (...)».

E há outros testemunhos coincidentes, alguns inéditos, do século XVII.

Portanto, aos olhos dos contemporâneos, era Camões um homem de grande cultura.

A investigação moderna confirma essa opinião, pela leitura das suas obras. E neste capítulo alguns dos mais entusiastas são os estrangeiros que escreveram sobre Camões.

$\mathrm{O}$ alemão Wilhelm Storck, traduzido para português pela sua compatriota Doutora Carolina Michaëlis de Vasconcelos, que foi uma das glórias da Universidade de Coimbra, escrevia $\mathrm{cm}$ 1898: "a quantidade e variedade de saber científico manifestado nas obras de Camões causa admiração, principalmente se considerarmos a raridade de bibliotecas volumosas, e o alto valor dos códices impressos e manuscritos que naquelas eras dificultava aos estudiosos as aquisições e até mesmo o uso dos livros. Mas admiração muito mais intensa desperta a fidelidade e segurança da memória do Poeta. Quer esteja em Coimbra, quer em Lisboa, em Ceuta, Goa, Malaca, Banda, Macau ou Moçambique, quer ande na terra ou vogue no alto mar, em toda a parte dispõe de multíplices e vastíssimos conhecimentos em História Universal, Geografia, Astronomia, Mitologia Clássica, Literaturas Antigas e Modernas, poesias culta e popular, tanto da Itália como das Espanhas, aproveitando-as com a mais perfeita exactidão, como filho legítimo do período do Renascimento e humanista dos mais doutos e distintos do seu tempon.

O inglês K. G. Jayne que em 1910 publicou Vasco da Gama and his successors, reimpresso seis décadas mais tarde, em 1970, na prestigiosa coleç̧ão Methuen Library Reprints, escreveu: «Na sua maior parte, os poemas escritos numa fase tardia da vida foram compostos longe de bibliotecas, numa época em que os livros eram objectos de luxo. Todavia, Camões revela um conhecimento íntimo da Literatura e da Mitologia Clássicas, de História, Geografia, Astronomia e das Literaturas de Portugal, Espanha e Itália. A sua familiaridade com, pelo menos, dezanove autores gregos e latinos foi demonstrada e alguns deles devem ter sido lidos no original, visto que nunca tinham sido traduzidos. Estes conhecimentos devem ter sido adquiridos em Coimbra e constituem o testemunho não só da sua aplicação ao estudo e memória tenaz, 
mas igualmente da plenitude com que Coimbra havia realizado os ideais do Humanismon.

Finalmente, e para não exceder o clássico número de três testemunhıs, citarei o americano Leonard Bacon que em 1950 publicou em Nova Iorque uma tradução inglesa em verso de Os Lusíadas, louvada pelos conhecedores de poesia naquela língua. O livro contém uma introdução sobre Camões, Portugal e a Europa contemporânea do poeta; um estudo sobre «Camões e a História de Portugal»; e ainda notas finais aos versos de Os Lusíadas, escritas com competência e, ocasionalmente, sentido de humor.

Numa dessas notas, ao comentar a precisão com que o poeta na estância 14. do canto $X$, versos 1 a 4, indica os inimigos de Duarte Pacheco, depois do combate do "passo Cambalão», não resiste a comentar: «Camões is almost as pedantically meticulous as a German Ph.D.» - «Camões é quase tão petulantemente meticuloso como um doutor alemão em Filosolia». Aliás, o trecho de Os Lusíadas comentado tem a ligeireza de toque do descritivo camoniano:

\section{Chamará o Samorim mais gente nova; \\ Virão Reis de Bipur e de Tanor \\ Das serras de Narsinga, que alta prova \\ Estarão prometendo a seu senhor.}

$\mathrm{O}$ que mais impressionou Leonard Bacon foi que Camões se não afastou um ápice da informação dos historiadores João de Barros e Damião de Góis, utilizando-os com um rigor quase científico.

As três opiniões citadas, a saber, de um alemão, um inglês e um americano, são, como vimos, unânimes em afirmar a grande cultura do poeta.

As duas primeiras, a de Storck e a de Jayne, insistem ambas na dificuldade em conseguir livros fora da Europa, nos lugares por onde Camões 98 andou, portanto, em Ceuta e no Oriente.

Em nota publicada em Janeiro de 1979 na revista Colóquio/Letras, mostrei com vários exemplos como a situação não era exactamente essa. A cultura europeia chegava ao Oriente com maior facilidade do que se pensava nos finais do século passado ou no princípio do actual. Os livros eram mais portáteis do que se julgava em 1898 ou em 1910, e circulavam na bagagem dos soldados. Também não eram a raridade nem a preciosidade de que o inglês Jayne falava. 
De entre os exemplos citados em Colóquio, e outros podiam ser apresentados, reterei neste momento aquele que me parece o mais significativo. Trata-se de um passo da famosa crónica dos tempos do rei D. Manuel, publicada em 1571 pelo bispo do Algarve, D. Jerónimo Osório, um dos mais célcbres prosadores em latim na Europa do seu tempo. Foi de 1537 a 1540 professor da Universidade de Coimbra e faleceu em 1580, passando, portanto, este ano o IV Centenário da sua morte. O livro a que me refiro chama-se abreviadamente De Rebus Emmanuelis gestis e teve, à data da publicação, grande eco no estrangeiro, por exemplo, em Inglaterra e na França. Foi traduzido para as línguas destes dois países, muito antes de o ter sido para português. Os Essais de Montaigne, para citar um caso apenas, reflectem um conhecimento da História de Portugal, pouco provável sem a Crónica dc D. Manuel, escrita em latim por Jerónimo Osório.

É aí que, referindo-se à batalha naval em frente a Diu, ganha em 2 de Fevereiro de 1509 por D. Francisco de Almeida contra uma esquadra internacional, escreve o bispo Osório: «Compunha-se o exército inimigo de tão variadas nações, que nos despojos das naus se encontraram livros escritos em latim, italiano, línguas eslavas, francês e espanhol». Cinco anos antes, em 1566, na sua Crónica do Felicíssimo Rei D. Manuel, Damião de Góis tinha dito que os livros eram «muitos»e acrescentara à lista dos idiomas o alemão e o português.

Isto passava-se no Oceano Índico, em 1509, portanto no começo do século XVI, e a produção bibliográfica aumentou muitíssimo nos meados do século, quando Camões andava pelo Oriente.

Todavia, bibliotecas particulares abundantes seriam uma raridade, e as públicas não eram numerosas. Ainda a mais acessível, e a mais rica, me parece a do Mosteiro de Santa Cruz de Coimbra, a avaliar pelo que ainda resta, guardado por Alexandre Herculano na Biblioteca Municipal do Porto.

Mas os livros de Santa Cruz só terão sido usados pelo poeta, nos anos da juventude, e a recordação de tantas e tão variadas leituras, nomeadamente de certas crónicas como as de Fernão Lopes, que estavam ainda manuscritas, supõe a posse de uma memória excepcional. Também este é mais um dado da educação humanística. Os mestres do século XVI treinavam os seus alunos na aquisição e conservação de uma retentiva poderosa e duradoura. Ainda recentemente, ao comparar as reminiscências camonianas dos poetas latinos Virgílio e Horácio, que aparecem em certos trechos da lírica do nosso Quinhentista, me dei conta da forma precisa como Camões conserva a lembrança 
de belos versos aprendidos certamente na infância e primeiros anos da juventude. Pois não quero crer que, para recordar o Mantuano ou o Venusino, tivesse Camões de ir consultar à pressa as edições destes famosos poetas.

Camões na Índia faz-me lembrar José de Anchieta, aluno de Coimbra, em terras do Brasil. De Anchieta, que chegou a Coimbra em 154.8, estamos mais bem informados. Foi discípulo de Diogo de Teive, o que supõe ter ele atingido o curso mais adiantado de Latinidade. Mas não concluiu o seu bacharelato em Artes, não foi documentalmente um bacharel latino, embora o tenha sido pela cultura que possuía. Entretanto, a memória excepcional, cultivada desde a infância, ajudou-o a compor, decerto com menor bibliografia do que Camões, porque também menos necessária, duas longas obras em verso dactílico latino, o Poema da Virgem Maria e o Poema dos Feitos de Mem de Sã (De Gestis Mendi Saa), este último anónimo mas muito provavelmente escrito pelo então chamado "canário de Coimbra", futuro P." José de Anchieta, mais tarde conhecido por Apóstolo do Brasil. $\mathrm{E}$ a propósito de Mem de Sá, recordemos que tanto ele como seu irmão, o poeta Sá de Miranda, eram naturais de Coimbra.

Voltando à questão das leituras de Camões e retomando a citação do inglês Jayne: «His familiarity with at least nineteen Greek and Latin authors has been demonstrated, and some of them must have been read in the original, as they had never been translated». Não sei bem o que este admirador britânico de Camões quer dizer com «alguns deles (dos autores gregos e latinos) devem ter sido lidos no original». Os latinos foram com certeza lidos no original. Quanto aos gregos, veremos mais adiante.

Hoje, possuímos informações sobre o movimento humanístico em Portugal, no começo do século XVI, que não estavam ao alcance das fontes bibliográficas de Jayne, nomeadamente de Teófilo Braga ou mesmo de D. Carolina Michaëlis, em 1910.

100 Não eram então conhecidos textos como a carta de Cataldo Parísio Sículo ao 2. Marquês de Vila Real sobre os méritos e vantagens culturais do latim clássico, carta escrita antes de 21 de Fevereiro de 1500; não era conlhecida a oração de sapiência do filho do Marquês o conde de Alcoutim, D. Pedro de Meneses, pronunciada perante o rei $\mathrm{D}$. Manuel que presidiu à abertura solene do ano lectivo na Universidade de Lisboa, em 18 de Outubro de 1504; e para me não alongar mais, era desconhecido o prólogo, fundamental e interessantíssimo, da Virginis Mariae Ars, a gramática latina de Estêvão 
Cavaleiro, saída dos prelos do alemão Valentim Fernandes, em Lisboa, no ano de 1516.

Ignoravam-se estes e outros documentos culturais importantes. E também se não conhecia a formação intelectual dos leigos do começo do século XVI que se imaginavam imersos na ignorância dos filhos d'algo e rudes barões da mais longínqua Idade Média. Não se imaginava, sequer, a educação literária recebida por homens como D. Jaime, duque de Bragança, aluno durante o exílio em Castela do humanista italiano Pedro Mártir d'Anghiera; como D. Jorge, duque de Coimbra e mestre das Ordens de Santiago e Avis, discípulo de Cataldo Parísio, também humanista e italiano; como D. Pedro de Meneses, 2. .9 conde de Alcoutim e futuro 3. marquês de Vila Real, aluno igualmente de Cataldo. De D. Pedro de Meneses, deixou-nos o seu mestre italiano um retrato em versos latinos na Visio Tertia ou Terceina Visão, poema em dísticos elegíacos.

O jovem conde de Alcoutim, por volta de 1510, segundo o seu panegirista, possui todos os dotes de um homem moderno, um homem do Renascimento: toca bem harpa, canta e dança na perfeição; compõe versos latinos e discursa em latim com a mesma facilidade com que derruba os adversários no jogo das canas, e toureia a cavalo, matando o touro de uma estocada. É prudente como Catão, eloquente como Cícero. Ter-se-iam apaixonado por ele, se o conhecessem, todas as heroínas da Antiguidade grega e romana.

Quatro séculos mais tarde, em 1910, e por muitos anos ainda, pensava-se que as Humanidades Greco-Latinas haviam entrado em Portugal com os professores de Bordéus, portugueses e estrangeiros que vieram com André de Gouveia, chamados por D. João III para fundar o Colégio das Artes em Coimbra, em 1548.

Ora, a correspondência e os poemas de Cataldo, confirmados por outra documentação contemporânea, permitem antedatar a entrada do Humanismo em Portugal, de cerca de cinquenta anos, isto é, colocar o seu aparecimento entre nós, no final do século XV.

E desta cultura nova, os mais ávidos alunos não eram os da nobreza, de que citei três grandes expoentes e podia citar outros ainda, como João Rodrigues de Sá de Meneses. Desejosos de valorizar-se pela aquisição do novo saber mostraram-se principalmente os elementos das classes situadas abaixo da nobreza. Desta avidez cultural que devorava os portugueses do começo do século XVI, tive ocasião de falar no meu livro Estudos sobre a Época do Renascimento e num artigo recente "Alguns aspectos da Introdução 
do Humanismo em Portugal», publicado no Boletim da Biblioteca Geral da Universidade de Coimbra, em 1979.

Era o tempo em que el-Rei D. João, «Segundo em nome e a ninguém segundo», falecido em 1495, mandava ensinar Latim aos meninos pretos da sua corte; e em que Martim de Sousa chamava de Sevilha um professor de Latinidade, para instruir os rapazes que combatiam sob as suas ordens no Norte de África. A carta em que Cataldo o felicita pela iniciativa é anterior a 1500. E tenho razões para crer que o mestre, ido de Sevilha, era um português e se chamava Estêvão Cavaleiro, como mostrei recentemente num artigo publicado no Festschrift für Harri Meier; Bonn, 1980.

Portanto, quando Camões nasceu, possivelmente em 1524, o latim clássico, veículo linguístico do Humanismo, não era uma raridade nestas plagas da antiga Lusitânia. A posse da língua latina era essencial à aquisição da cultura do Renascimento, pois todos os livros importantes de todas as ciências estavam escritos em latim e os intelectuais de um país distante como Portugal, onde se falava uma língua ignorada na Europa, os estudiosos Portugueses estavam então em condições de andar em dia com a cultura contemporânea mais facilmente do que hoje.

Na verdade, um conhecimento em primeira mão do que se publica lá fora, em nossos dias, exige o domínio de duas ou três línguas, além da própria, enquanto no Renascimento, o latim, como idioma universal da cultura, servia para todas as necessidades do intercâmbio científico.

Portanto, para possuir a cultura, não apenas literária, mas também científica que Os Lusiadas revelam, precisava Camões de conhecer bem a língua latina. E todos os indícios confirmam a opinião de que assim acontecia de facto.

A abundância e variedade da sua informação levaram mesmo a admitir a hipótese de que o poeta não tivera um convívio directo com todos os autores de que mostra ter conhecimento. Houve quem supusesse que the teriam servido de guia enciclopédias então existentes, como a Offícina de Ravisius Textor, nome latino do francês Jean Tixier de Ravisy, ou os Antiquarum Lectionum Libri Sedeciun do italiano Caelius Rhodiginus. Mas até esses estão escritos na língua sábia do tempo.

Pessoalmente, estou convencido de que o imenso conhecimento da Literatura Latina que o Poeta revela, foi adquirido directamente. Autores como Cícero e os poetas da época de Augusto, Camões devia sabê-los de cor. $\mathrm{E}$ a juntar a estes um conhecimento de poetas modernos, quer italianos como 
Petrarca e Ariosto, quer espanhóis, como Garcilaso e Boscán, quer novilatinos, como Pontano e Sannazaro. As obras de humanistas nacionais, por exemplo, André de Resende e Jorge Coelho, ou estrangeiros como Boccaccio e Marcantonio Sabelico, dos historiadores e cronistas Portugueses, Fernão Lopes, Rui de Pina, João de Barros, Castanheda e Duarte Galvão foram arroladas pelo Prof. José Maria Rodrigues nas suas Fontes dos Lusíadas, livro de mais de seiscentas páginas que a Academia das Ciências acaba de reeditar.

A espantosa cultura literária do poeta não the fechava os olhos para outras disciplinas do saber. Aliás, a curiosidade pela ciência e pela vida era muito maior no século XVI do que geralmente se julga. Não tendo as ciências atingido o desenvolvimento e a especialização actuais, não era difícil a um jurista e médico, alcançarem uma apreciável informação da rainha das ciências do tempo, mesmo em pleno Renascimento europeu, a Teologia. E médicos, juristas e teólogos haviam feito preparatórios mais ou menos extensos, conforme os casos, em cursos de Artes. Por outro lado, era normal num graduado em Artes que ele possuísse uma informação apreciável de todas estas disciplinas.

Admitindo que Camões fez estudos de Humanidades, não parece fora de propósito aceitar que por esta via tenha lançado os fundamentos para uma cultura que irá desenvolver ao longo de toda uma vida de estudo, apenas ocasionalmente interrompida por actividades militares. Já vimos que os livros circulavam mais facilmente do que se julgava no princípio do século vinte.

Acresce que o humanismo não era só culto da Antiguidade. O latim, como já tive ocasião de dizer, abria as portas para a universalidade de uma cultura que ia muito além do mundo de gregos e romanos e das tradições locais, pois englobava toda a ciência que a Europa produzia.

É bem sintomático que um dos livros que ao longo do século XVI os humanistas mais se esforçam por reconstituir no seu texto original seja a Historia Naturalis de Plínio-o-Velho, o mais completo repositório de observações sobre a Natureza que a Antiguidade nos legou. Na vizinha Universidade de Salamanca, funcionava uma cadeira de Plínio, e em Lisboa, quando a Universidade aí se encontrava, na segunda década de Quinhentos, leccionou sobre Plínio, com grande audiência de pessoas interessadas, universitárias e da corte, o jurista Martim Figueiredo, que fora aluno de Ângelo Poliziano em Florença, antes de 1494. Do êxito das suas aulas em Lisboa, informa-nos o Doutor Figueiredo no Comentário ao Prólogo da História Natural de Plínio, livro escrito em latim que publicou em Lisboa, em 1529. 
Mas há outros testemunhos da curiosidade científica dos humanistas:

Diogo de Teive foi uma das estrelas do Colégio das Artes de Coimbra, para onde veio do Collège de Guyeme de Bordéus. Fora um dos bolseiros, cujos estudos em França a coroa Portuguesa subsidiara, durante muitos anos. Hoje, é mais conhecido pela sua História do Segundo Cerco de Diul, em 1546, livro que na época tornou este feito dos Portugueses célebre em toda a Europa, graças à língua comum em que foi escrito. É uma obra ainda actual, traduzida para inglês, há meia dúzia de anos, mas inexistente em língua portuguesa.

Teive era também poeta. Entre outros poemas, deixou-nos uma Tragédia do Príncipe João sobre a morte, trágica para a independência de Porlugal, do filho de D. João III e pai de D. Sebastião, ocorrida em 1554. Traduziu-a do latim a Dr. - Nair Soares, em 1977.

Pois bem, historiador, poeta e dramaturgo, Teive, na sua infinita curiosidade de homem da Renascença, ocupava os poucos lazeres de um professor do século XVI, percorrendo os campos de Coimbra, com colegas e alunos, para recolher e estudar as plantas. Isto mesmo declarou ele, em Outubro de 1550, num depoimento autobiográfico em latim que se encontra apenso ao seu processo na Inquisição. Como se vê, as pesquisas botânicas de Garcia de Orta na Índia, não eram um caso isolado nem exclusivas da prolissão médica.

Há nos Lusíadas sinais numerosos deste gosto pela observação da Natureza, desde o mar bonançoso com a brisa suave a enfunar as velas dos navios até aos momentos dramáticos do encontro com o desconhecido, como nas estâncias célebres do canto $\mathrm{V}$, em que o poeta descreve a tromba de água.

A educação livresca não prejudicou em nada a espontaneidade do poeta. A posse da cultura do seu tempo, adquirida na escola, não esmoreceu nele o surto da criatividade.

Sim, porque estou convencido de que Camões fez estudos regulares,

104. embora, à semelhança do que aconteceu com tantos outros, não tenha a sua escolaridade ficado registada em livros de matrículas ou de actos que chegassem até nós. Esses estudos foram provavelmente os dos cursos de Artes do Mosteiro de Santa Cruz, em Coimbra. Tê-los-á concluído? Terá sido bacharel em Artes ou bacharel latino, como se dizia no seu tempo? Não há documentos que o provem. Aliás, a designação de «bacharel latino» era provavelmente usada para caracterizar uma pessoa culta, versada na língua latina, sem que o título implicasse necessariamente a posse de um diploma. 
De vez em quando, levanta-se também a questão de saber se Camões conhecia ou não a língua grega. Ultimamente, a ignorância do Grego, assacada a Camões, serviu ao autor de certa Vida do poeta para provar que este não frequentara estudos regulares e muito menos em Coimbra.

Ora a obrigatoriedade de falar grego antigo, ou mesmo de estudar grego, não existia em qualquer das constituições quinhentistas ou planos escolares conhecidos. Por outro lado, parece-me de todo contrária ao espírito curioso e indagador do poeta, a falta nele dos rudimentos duma língua que, então, outros estudantes não ignoravam.

Em todo o caso, os argumentos que tenho lido, destinados a provar que Camões não sabia Grego, são demasiado frágeis para lograrem convencer-me. E uma coisa é certa: se me parece difícil provar a ignorância helénica de Camões, tal ignorância, em compensação, é para mim evidente no mais conspícuo defensor actual dessa tese. Mas prossigamos!

A cultura grega, os oradores poetas, historiadores e filósolos da Grécia Antiga, cujo conhecimento era indispensável ao homem culto da Renascença, estavam então traduzidos para latim. Acresce que a substância da cultura grega fora absorvida pelos melhores espíritos de Roma e transmitida à posteridade nessa simbiose cultural greco-latina que constitui o cerne mesmo da civilização ocidental.

Em relação a Camões, vários membros da nossa Universidade discutiram no decorrer deste século o platonismo de certos poemas, como as redondilhas «Sôbolos rios».

Nelas, o conhecimento da Filosofia de Platão é inegável. Trouxeram contributos valiosos e reflectidas sugestões, mestres da craveira de Joaquim de Carvalho e Costa Pimpão. Mas parece-me que a visão mais construtiva e original do problema das fontes do Platonismo de Camões se deve a um jovem licenciado em Filologia Clássica que, em 1942, retomou o assunto no volume XVIII da revista Biblos da Faculdade de Letras da Universidade de Coimbra, com um artigo intitulado «Teria Camões lido Platão?». Chamava-se o novel estudioso Vergílio António Ferreira e é hoje o consagrado romancista Vergílio Ferreira.

Mostrou ele como algumas das ideias básicas de cariz platónico que informam o poema "Sôbolos rios" se podem encontrar nas "Tusculanae Disputationes», as «Discussões em Túsculo» ou "Tusculanas», diálogo filosófico de Cícero que foi um dos livros mais divulgados no fim da Idade Média e no Renascimento. 
Numa altura em que o latim se começava a estudar aos seis anos de idade, quando não dois ou três anos antes, as Tusculanas eram leitura já feita, aos catorze anos. Estes comentários sobre id'ades são meus. De Vergílio Ferreira é a sugestão das semelhanças entre Tusc. Disputationes I, XXIV, 56-57, e os passos mais platonizantes de «Sôbolos rios». Aliás, Cícero menciona nesse trecho repetidamente Platão e os diálogos em que o filósofo grego se ocupa de «memória» e "reminiscência».

Eis uma via de pesquisa ainda não explorada pelos nossos investigadores, esta dos intermediários latinos da divulgação da filosofia grega em Camões. Aliás, não admira que esta linha tenha sido descorada, quando tantas outras podem a priori ser aceites: a leitura dos poetas, italianos e espanhóis, em que ideias semelhantes podem encontrar-se, o conhecimento dos platonistas do Renascimento, enfim, todo o mundo de conceitos que então andava no ar e o latim dos humanistas tornava acessível por essa Europa fora.

Mas em que ficamos, quanto à escolaridade do poeta? Por falta de documentos, não podemos ir além de impressões. Impressões com fundamento, todavia. A cultura de Camões é séria, sólida, sedimentada. Nada denuncia nela o autodidacta, mas o homem que na altura própria adquiriu os fundamentos do saber do seu tempo e depois não deixou de cultivar-se pela vida adiante. Como já disse, lembra-me Anchieta que teve uma formação escolar igualmente cuidada, embora não tenha concluído o Curso de Artes.

Hoje, Anchieta é um dos mais famosos antigos alunos de Coimbra, do outro lado do Atlântico, por estar em marcha o seu processo de canonização no qual estão profundamente interessados os brasileiros.

Sabe-se que José de Anchieta foi aluno do humanista Diogo de Teive que regia a classe mais adiantada de Latinidade, e aluno brilhante, como provam ainda hoje os dois longos poemas latinos que nos deixou. Mas não existe nem a matrícula nem qualquer documento do Colégio das Artes a seu respeito.

Em nota publicada na revista Humanitas, XXIX-XXX, mostrei que se 106 pode concluir a sua presença em Coimbra, a partir de 1548, através de um documento relativo a seu irmão mais velho Pedro, com quem o moço José de Anchieta veio para Coimbra.

Ora a respeito de Pedro, que foi aluno da Faculdade de Cânones, também não existe qualquer registo de matrícula. Mas acontece que, seis anos depois de ter chegado a Coimbra, apresentou em 1554 duas testemunhas que declararam haver ele frequentado cursos de Cânones, a partir de Outubro do 1548 . 
Os processos de matrícula eram tão incertos, tão irregulares que, geralmente, só quando o aluno estava para concluir o curso, concorrendo aos exames finais, provava com testemunhas ter frequentado o número de cursos necessários para se apresentar aos actos. O mesmo aconteceu com André Falcão de Resende, a quem adiante me referirei.

Existe um "livro da Matrícula dos Estudantes" dos Colégios do Mosteiro de Santa Cruz, entre 1534 e 154.0, que se encontra na Torre do Tombo e foi publicado pelo Doutor Cândido dos Santos. Todavia, admitindo que essas listas estão completas (e nada nos garante que assim seja!), apenas provam que Luís de Camões não frequentou os Colégios de Santa Cruz, entre 1534 e 154.0.

Além dessa série de nomes, há outras no Arquivo da Universidade de Coimbra, por exemplo a dos alunos de Lopo Galego em 1537. Mas tudo isso é fragmentário e incompleto.

A situação dos registos escolares era tão aventurosa, já no tempo de Camões, que lembro só mais um caso. Certo dia, em 1558, o professor de Grego, o bem conhecido Vicente Fabrício, precisou de uma certidão do seu grau de Mestre em Artes que obtivera em Coimbra. Pois teve de recorrer ao processo das testemunhas. Afirmaram os professores Afonso do Prado e Diogo de Gouveia "que haveria vinte anos que tomara o dito grau nesta Universidade».

A propósito dos estudos de Camões, um texto muitas vezes citado é a "Sátira II - A Luís de Camões» de um poeta, bacharel em Artes pela Universidade de Évora e licenciado em Cânones pela Universidade de Coimbra, chamado André Falcão de Resende.

Note-se que André Falcão, nome por que era mais conhecido no tempo, começou a frequentar Cânones em Coimbra, em 1548, e terá ficado na Universidade até 1550 , interrompendo então o curso que só veio a retomar em 1567. Nesse ano não havia qualquer registo da sua presença na Universidade, dezanove anos antes, e a prova foi feita pelo próprio André Falcão, "pelo juramento dos avangelhos», apresentando como testemunla Bartolomeu Rodrigues Monteiro que termina assim a sua confirmação: «\& sabe ele $t^{\underline{a}} \tilde{\mathrm{q}}$ hia as escolas \& tinha Iyuros \& era estudãte \& nõ se afirma ele $t^{\underline{a}}$ se esteue todos os Anos Jnt mas sabe $\widetilde{\mathrm{q}}$ esteue A mayor parte deles \& $\widetilde{\mathrm{q}}$ jsto ser tĩ Antigo \& de tãtos Anos nõ se firma nas cousas miudam porẽ sabe $\widetilde{\mathrm{q}}$ era estudãte he hia as escoJas cursar \& tinha Liuros he casa \& era mº amigo de seus jrmãos he tjo \& asjuna

Bertolameu roiz mõt ${ }^{\text {to }}$." 
O tio assim tão inopinadamente lembrado era o mais conhecido André de Resende e o seu nome deve ter sido aduzido para dar alguma autoridade a um testemunho, de si bastante precário.

Feito este parêntese, detenhamo-nos um pouco em alguns versos da «Sátira a Luís de Camões», composta por André Falcão de Resende que the juntou o subtítulo: «Reprende aos que, desprezando os doutos, gastam o seu com truhães".

O grave juiz-poeta Falcão de Resende enumera os inconvenientes a que se sujeita quem faz versos:

Logo algum vil esp'rito o nota e acusa:

"Vedes o triste» - diz aos do seu bando -

"Que é bacharel latino, e nada presta,

"É poeta o coitado, é monstro nefando.

"Na noite, que mal dorme, ou ardente sesta

"Compóe sonetos por seu passatempo,

"E sua pequice em versos manifesta.

"Melhor the fora aproveitar o tempo

"Em chatinar fazenda, em conta, em caixa,

"Andar trás o dinheiro, audar c'o tempo,

"Gastar mil iguarias, vestir raxa,

"Cheirar, jogar, folgar, seguir pagodes,

"Que mal comer, vestir sempre por taxa.

E mais adiante;

"Ande o pobre poeta um doudo feito,

"Medicando o comer e os consoantes,

"Compondo seus poemas sem proveito.

"Bem tenho eu" - diz o vil - "por mais galantes

108 "os truhães chocarreiros com guitarras,

"Que aplazem aos reis, aos príncipes e infantes.

"Estes alegres com c'roas de parras

"Festejam Baco e Ceres todo o ano,

"E o prazer tem seguro a quatro amarras.

"Nunca lhes falta o pão, calçado e o pano,

"Seja um doudo, é Dom Félix, Dom Briando,

"E bem que parvo, é ciceroniano. 
Tem-se discutido quem é o bacharel latino, se Camões, se Falcão de Resende. Este último sabemos nós que tinha alcançado esse grau na Universidade de Évora, sua terra natal, enquanto estivera ausente de Coimbra. Mas nada indica que, no trecho citado, o título de bacharel pertença apenas a Falcão de Resende.

Wilhelm Storck, o minucioso biógrafo alemão de Camões pensava que o bacharel latino só se aplicava a Falcão de Resende, porque nenhum documento atribui a Camões uma formatura em Direito. Mas a verdade é que bacharel latino era uma designação de graduado em Artes, curso que, aliás, também nenhum documento atribui a Camões, e que André Falcão se licenciara em Direito Canónico. Penso ser provável - como atrás disse - que o qualificativo de «bacharel latino» se aplicasse a qualquer homem que tinha feito estudos, era cultivado e sabia o seu latim, independentemente da posse do pergaminho. E é deste modo que creio ter sido Luís de Camões estudante de Artes ou até de outra Faculdade, embora provavelmente não tenlıa concluído o curso. Mas a solidez e segurança da sua cultura denunciam estudos regulares, feitos cedo, como era costume então.

Onde estudou Camões? Em Coimbra? Parece mais provável do que em Lisboa. Com efeito, as próprias cartas que lhe são atribuídas, e se me aliguram autênticas, testemunham mais uma vida dissipada do que uma existência de estudioso, para o período de permanência na capital. Aliás, os estudos Superiores estavam então em Coimbra.

Se nos Lusíadas invoca as ninfas do Tejo, é porque este rio simboliza a grandeza histórica e política e convém à majestade da epopeia, como berço das naus do Oriente. $\mathrm{O}$ rio que banha Coimbra, mais modesto, sugeria então a quietude dos costumes pastoris e o ambiente da bucólica, «nos saudosos campos do Mondego» (III, 120).

Além disso, para as divindades do Tejo, segundo a tradição poética greco-latina, Camões encontrou já uma palavra feita, corrente na poesia dos humanistas portugueses. As ninfas do Tejo eram as Tágides, de Tagus, nome latino do rio. O criador da palavra "Tágides" foi, como é sabido, André de Resende, o mesmo a quem Camões deve a palavra Lusíadas.

A partir de Mondego, não era possível formar uma palavra com tanta facilidade, ou o bom gosto do poeta, habilíssimo em introduzir latinismos em português, não achou conveniente formá-lo do latim Munda, nome romano do rio. Daí que existam, por um lado as Tágides, e por outro as «ninfas do Mondego", também chamadas "filhas do Mondego» numa das mais formosas 
estâncias de Os Lusíadas, com que termina o episódio de Inês de Castro c que muitos dos que me ouvem recordarão neste momento:

As filhas do Mondego a morte escura

Longo tempo chorando memoraram,

E por memória eterna em fonte pura

As lágrimas choradas transformaram;

O nome the puseram, que inda dura,

Dos amores de Inês que ali passaram.

Vede que fresca fonte rega as flores

Que lágrimas são a águá, e o nome amores.

Mas no canto VII, a abrir uma série de considerações sobre a sua vida que constituem, ao mesmo tempo, um trecho de sentida e vibrante crítica social, Camões coloca as ninfas dos dois rios, par a par:

Um ramo na mão tinha... Mas, ó cego,

Eu, que cometo insano e temerário,

Sem vós, Ninfas do Tejo e do Mondego,

Por caminho tão árduo, longo e vário!

Vosso lavor invoco, que navego

Por alto mar, com vento tão contrário,

Que se não me ajudais, hei grande medo,

Que o meu fraco batel se alague cedo.

As ninfas do Tejo, as Tágides, tinham sido invocadas no começo do poema, quando a tarefa do poeta se antolhava mais fácil e era iniciada com um belo entusiasmo. Mas num momento de cansaço, quando a desilusão com

110 os homens e a indignação pelas suas injustiças faz soar uma nota de desalento, Camões recorre não apcnas às Tágides, mas também às Ninfas do Mondego, deusas tutelares que o protejam e defendam do seu próprio desânimo: «Ninfas do Tejo e do Mondego!».

As do Tejo, sabemos nós ao que vêm, são as Tágides da lírica e da épica que o pocta refere com gosto nas estâncias 4 e 5 do canto I. $\mathrm{E}$ as do Mondego? Não serão as que recordam a "Alma Mater Conimbrigensis", os dias distantes em que o poeta lia o seu Virgílio, modelo do Bucolismo e da Epo- 
peia, e sonhava imitá-lo? Elas estão presentes nas memórias do tempo passado:

Vão as serenas águas

do Mondego descendo

mansamente, que até o mar não param;

por onde minhas máguas,

pouco a pouco crecendo,

para nunca acabar se começaram.

(Canção IV)

Em 1607, um mercador de livros de Coimbra, chamado Domingos Fernandes, resolveu homenagear a Universidade que the dera o encargo, como ele diz, de «feitorizar a sua Liuraria Publica». E na portada de uma edição da lírica fez imprimir este título: Rimas de Luis de Camões. Acrescentadas nesta Terceyra impressaõ. Dinigidas à inclyta Universidade de Coimbra, (...) A cusla de Domingos Fernandez mercador de libros.

A dedicatória um tanto empolada, de que lerei uma frase, exprime o alto conceito em que o poeta era lido, cerca de três décadas após a sua morte: "Não sabemos, que ao mais alto lugar da humana Poesia, tenha dado o Mundo mais que um Homero, Grego: um Virgílio, Latino: hum Tasso, Italiano; \& hum Camões, Portuguez: como quatro immortaes columnas de tão soberano templo. Como podem logo ser defendidas columnas tão altas, \& tĩo fortes, que ellas mesmas não sejão? sendo ellas continuamente combatidas pelos furiosos ventos dos invejosos».

Por outras palavras, Domingos Fernandes quer dizer que para defender e exaltar Camões só uma instituição cujo prestígio intelectual se compare com o do grande poeta.

E daí parte para um elaborado elogio da Universidade em que o motivo central é a comparação da alma Mater com a figura feminina, cujo busto se ergue sobre o cálice no brasão da cidade de Coimbra. Ouçamo-lo;

"Pois se vós (verdadeira exposição da coroada Princesa das misteriosas armas de Coimbra) sois esta que dizíamos, para as mais propinquas e remotas partes do Universo: e per nacimento e criação, per ofício e per obrigação, fostes também a mesma, para com o vosso grande Luís de Camões: pois 
nacendo elle nessa vossa cidade de Coimbra, la vosso peyto, como Mãy natural o criastes tantos annos: com vossa doutrina, como Mestra, o ensinastes algunos: e com vossos louvores, como fiel Amiga, o louvastes tantas vezes. A quem, senão a vós, se deve encomendar esta Proteição, de um vosso Filho, Discípulo \& Amigo: e mais, sendo ele ja morto para se não poder defender: e ainda vivo, para poder ser ofendido.»

Até aqui a retórica sonora e fácil, e quiçá também calculista, do livreiro Fernandes. Ela sugere, todavia, a existência de uma tradição universitária de Camões em Coimbra, menos de trinta anos depois do desaparecimento do poeta.

A naturalidade conimbricense é, a seguir, substituída pela de Lisboa na edição dos Lusíadas, comentada pelo Lic.. Manuel Correia e publicada em 1613. Aí vem a primeira biografia do poeta, da autoria de Pedro de Mariz, que copia a informação de Manuel Correia sobre o nascimento em Lisboa, mas se não refere aos estudos do poeta, nem em Coimbra, nem em qualquer outra parte. Mariz, aliás, era muito mais jovem que Camões, pois nascera pela mesma altura em que se pensa residir o poeta em Ceuta.

O editor é igualmente Domingos Fernandes que passa agora a dedicar o livro a D. Rodrigo da Cunha, «Inquisidor Apostólico do Santo Ofício de Lisboa». Sabe-se que Fernandes esteve preso nos cárceres da Inquisição.

É possível que as relações do livreiro com a Universidade tenham sofrido mudança, pois num outro livro camoniano, uma nova edição das Rimas, em 1616, também dedicada a D. Rodrigo da Cunha, já então «bispo de Portalegre e do Conselho de Sua Majestade», Fernandes diz em louvor do célebre prelado: «foy servido appadrinhar a restauração da minha honra e vida, que eu tinha tão perdida, \& acabada, que para desesperar de todo remé112 dio dellas, me via algũas vezes em o último termo".

Se nos lembramos de que D. Rodrigo da Cunha fora «inquisidor» e de que a Inquisição tinha que ver com a censura e aprovação dos livros, talvez o livreiro-editor que era Domingo Fernandes, alguma razão encontrasse para preferir um patrono concreto a uma entidade relativamente vaga e impessoal como a Universidade.

A próxima vida, quarenta e quatro anos após a morte de Camões, é a de Manuel Severim de Faria, publicada em Évora, em 1624. Aí se diz que 
Camões nasceu «na cidade de Lisboa, como o testifica Manoel Correia seu comentador, que o conheceu, \& foi seu familiar amigo e não $\mathrm{em}$ Coimbra, como alguns cuidaram, pela vivenda antiga que seus Avôs ali tiveram». E acrescenta: "Sendo moço, foi estudar a Coimbra, que então começava a florecer em todas as sciencias por beneficio d'El Rey Dom João III...».

A tradição da escolaridade coimbrã continua posteriormente. A sua relutação aparece como um fenómeno tardio, baseada na ausência de documentos que confirmem a presença do poeta nas escolas conimbricenses. Razão de peso, porque a História faz-se sobre documentos, mas, depois do que para trás ficou sobre as vicissitudes do acaso na conservação das memórias académicas do século XVI, razão, afinal, menos convincente do que a priori podia parecer.

A verdade é que, se existe subjectivismo em admitir que Camões estudou em Coimbra, não são menos subjectivas certas opiniões em contrário, como a mais recente que vou apresentar.

Ainda há pouco, num livro muito falado, e talvez menos lido do que falado, se declarava a propósito da estância 97 do canto III de Os Lusíadas, dedicada ao rei D. Dinis e à Universidade que ele fundou: «E naquela única referência à cidade universitária e às insígnias académicas não se encontra qualquer inflexão de ternura, saudade ou orgulho, sentimentos que nunca faltam em quem estudou em Coimbra».

$\mathrm{O}$ autor destas palavras não foi, evidentemente, estudante de Coimbrà. Para opor à sua opinião, citarei outra de um categorizado filho da «alma Mater Conimbrigensis». Será ele D. Francisco Alexandre Lobo que em 1787 aqui se doutorou em Teologia e foi professor entre 1808 e 1819, ano em que deixou o magistério universitário para ir ocupar a Sé de Viseu.

A sua «Memoria Historica e Critica ácerca de Luiz de Camões e das suas Obras», publicada em 1821 pela Academia das Ciências, e reimpressa em 1848, é um trabalho, cuidadosamente elaborado e bem escrito, que ainda hoje se lê com proveito. Tratando dessa mesma estância, escreveu D. Francisco Alexandre Lobo: «... (Camões) bem parece fallar com a paixão e fogo de hum alumno, que se recorda saudosamente agredecido, da escola em que tomou lições e formou seu espírito na mocidade». E, em nota, comentava: «Se destes argumentos não resulta inteira certeza, a crítica mais dificultosa em se dar por satisfeita, não pode ao menos negar, que resulta muito alto grau de probabilidade». 
Seja-me permitido, Magnífico Reitor, fazer minha tão sensata observação, e terminar estas palavras com a leitura da mesma estância 97 do canto III de Os Lusíadas:

Fez primeiro em Coimbra exercitar-se

$O$ valeroso ofício de Minerva

E de Helicona as Musas fez passar-se

A pisar do Mondego a fértil erva.

Quanto pode de Atenas desejar-se,

Tudo o soberbo Apolo aqui reserva,

Aqui as capelas dá tecidas de ouro,

Do bácaro e do sempre verde louro.

Tenho dito. 

Série

Documentos

Coimbra

Imprensa da Universidade

2005 